\title{
Pharmacological characterization of a nociceptin receptor from zebrafish (Danio rerio)
}

\author{
Ángel A Rivas-Boyero ${ }^{1 *}$, M Javier Herrero-Turrión ${ }^{2 \star}$, Veronica Gonzalez-Nunez ${ }^{1,2 *}$, \\ Fátima Macho Sánchez-Simón ${ }^{1,2}$, Katherine Barreto-Valer ${ }^{1,2}$ and Raquel E Rodríguez ${ }^{1,2}$
}

${ }^{1}$ Department of Biochemistry and Molecular Biology and ${ }^{2}$ Institute of Neurosciences of Castilla y León (INCYL), University of Salamanca, 37007 Salamanca, Spain

(Correspondence should be addressed to R E Rodríguez; Email: requelmi@usal.es)

*(Á A Rivas-Boyero, M J Herrero-Turrión and V Gonzalez-Nunez contributed equally to this work)

\begin{abstract}
The nociceptin receptor (NOP) and its endogenous ligand, nociceptin/orphanin FQ (OFQ), are involved in a wide range of biological functions, such as pain, anxiety, learning, and memory. The zebrafish has been proposed as a candidate to study the in vivo effects of several drugs of abuse and to discover new pharmacological targets. We report the cloning, expression, and pharmacological characterization of a NOP receptor from zebrafish (drNOP). The full-length cDNA codes a protein of 363 residues, which shows high sequence similarity to other NOPs. Phylogenetic analysis indicates that NOPs are broadly conserved during vertebrate evolution, and that they stand for the most divergent clade of the opioid/OFQ receptor family. Expression studies have revealed that drNOP mRNA is highly expressed in the central nervous system, and low expression levels are also found in peripheral tissues such as gills, muscle, and liver. Pharmacological analysis indicates that drNOP displays specific and saturable binding for $\left[\right.$ Leucyl-3,4,5- $\left.{ }^{3} \mathrm{H}\right]$ nociceptin, with a $K_{\mathrm{d}}=0.20 \pm 0.02 \mathrm{nM}$ and a $B_{\max }=1703 \pm 81 \mathrm{fmol} / \mathrm{mg}$ protein. $\left[{ }^{3} \mathrm{H}\right]$ Nociceptin binding is displaced by several opioid ligands such as dynorphin A (DYN A), naloxone, bremazocine, or the $\kappa$-selective antagonist nor-binaltorphimine. $\left[{ }^{35} \mathrm{~S}\right]$ GTP $\gamma$ S stimulation studies showed that drNOP receptor is functional, as nociceptin is able to fully activate the receptor and DYN A behaves as a partial agonist (50\% stimulation). Our results indicate that drNOP receptor displays mixed characteristics of both NOP and $\kappa$ opioid receptors. Hence, drNOP, which has retained more of the likely ancestral features, bridges the gap between nociceptin and opiate pharmacology.
\end{abstract}

Journal of Molecular Endocrinology (2011) 46, 111-123

\section{Introduction}

The opioid receptor-like 1 (ORL1) or nociceptin receptor (NOP) is a G-protein-coupled receptor (GPCR) that exhibits a significant degree of sequence identity with the three opioid receptors: $\mu$ (MOR), $\delta$ (DOR), and $\kappa$ (KOR; Waldhoer et al. 2004). Despite this sequence similarity, mammalian NOPs display different pharmacological characteristics, since they do not recognize opioid ligands, such as morphine or naloxone (Meunier et al. 1995, Reinscheid et al. 1995). The endogenous NOP ligand, nociceptin/orphanin FQ (N/OFQ), is a peptide of 17 residues (Meunier et al. 1995) which displays high sequence similarity to dynorphin A (DYN A), the prototypical $\kappa$ peptide. NOP activation has been associated with numerous biological processes, including spinal analgesia, supraspinal hyperalgesia, inhibition of locomotor activity, anxiolytic-like effects, stress, stimulation of feeding, diuresis, antagonism of opioid-induced effects, and depression of the cardiovascular system (Mogil \& Pasternak 2001, Waldhoer et al. 2004, Chiou et al. 2007). Besides, it has been suggested that NOP plays an important role in many complex processes, such as in learning and memory, attention and emotions, movement and motor processes, homeostasis and neuroendocrine secretion (Meunier 1997). Also, expression analysis has revealed that this receptor shows a widespread distribution in both the central (CNS) and the peripheral nervous system (Mollereau \& Mouledous 2000).

To date, several NOP genes have been cloned and/or identified from different mammalian species (Homo sapiens, human (Mollereau et al. 1994); Rattus norvegicus, rat (Nishi et al. 1993, Fukuda et al. 1994, Lachowicz et al. 1995); Mus musculus, mouse (Pan et al. 1996); Mesocricetus auratus, golden hamster; Cavia porcellus, guinea pig; Sus scrofa, pig (Osinski et al. 1999); Canis familiaris, dog; Equus caballus, horse; Monodelphis domestica, opossum; and Ornithorhynchus anatinus, platypus), chicken (Gallus gallus), from three amphibian species (Taricha granulosa, rough-skinned newt (Walthers et al. 2005); Rana pipiens, northern leopard frog (Stevens et al. 2007); and Xenopus laevis, African clawed frog), and chondrostean Acipenser transmontanus, white sturgeon (McClendon et al. 2010). 
However, the existence of a functional NOP in teleosts was still unknown.

Our research group has cloned and characterized the opioid receptors from zebrafish (dr: Danio rerio): drDOR1, drDOR2, drMOR, and drKOR. Besides, we have also characterized the opioid precursors, namely two proenkephalins, two proopiomelanocortins, a prodynorphin (PDYN), and a pronociceptin (PNOC; for a complete review of the zebrafish opioid system, please refer to Gonzalez-Nunez \& Rodriguez (2009)). Interestingly, $d r P N O C$ codes for two different nociceptin peptides: drNOC (YGGFIGIRKSARKWNNQ) and drNOC-like (FGGFMKGRHGLRKLVSSGRPLQ; GonzalezNunez et al. 2003). The fact that drNOC contains the classical 'opioid message' -Try-Gly-Gly-Phe- instead of the 'NOP message' -Phe-Gly-Gly-Phe-, and that the synthetic ligand Tyr-nociceptin binds to NOP as well as to $\kappa$ and $\mu$ opioid receptors (Reinscheid et al. 1996, Lapalu et al. 1997), led us to think that the zebrafish NOP might show high affinity not only for N/OFQ, but also for opiate ligands, especially for the $\kappa$ agents. This hypothesis was previously postulated by Danielson et al. (2001) in their work with the sturgeon orphanin and by Walthers et al. (2005) in the characterization of the nociceptin receptor from the rough-skinned newt.

Additionally, the teleost zebrafish is a suitable animal model to study development and to gain insight into the molecular mechanisms of some human diseases (Lieschke \& Currie 2007). Besides, it is possible to conduct chemical screenings to establish the in vivo effect of novel chemical agents and to perform toxicological investigations (Zon \& Peterson 2005). In addition to this, recent studies have revealed that teleosts are capable of experiencing pain, and a whole issue of the ILAR Journal was dedicated to this topic ('Pain and Distress in Fish', vol. 50, 2009). On the other hand, the ethical considerations that arise when using the zebrafish as an alternative model in pain research will stand for a clear advantage as compared with mammalian models.

In the present study, we report the cloning, gene expression, and pharmacological characterization of a NOP from zebrafish (drNOP). Our results indicate that NOP genes have been broadly conserved during the course of vertebrate evolution, although significant changes in their functionality might have occurred.

\section{Materials and methods}

\section{Drugs and radioligands}

[Leucyl-3,4,5- $\left.{ }^{3} \mathrm{H}\right]$ Nociceptin $(82 \cdot 3 \mathrm{Ci} / \mathrm{mmol})$ was purchased from Perkin-Elmer (Boston, MA, USA). Bremazocine (Bre), naloxone $(\mathrm{Nx})$, nor-binaltorphimine (nor-BNI), and porcine DYN A (1-17) (mammalian,
mDYN A) were purchased from Sigma-Aldrich, and nociceptin was purchased from Bachem GmbH (Weil am Rhein, Germany). Zebrafish DYN A (drDYN A) was synthetized as trifluoroacetic derivative by $\mathrm{G}$ Arsequell and G Valencia at the Consejo Superior de Investigaciones Científicas (Barcelona, Spain). All other reagents used were of analytical grade.

\section{Animals}

Adult zebrafish were obtained from commercial suppliers and kept in aquaria at $25-28{ }^{\circ} \mathrm{C}$ with $12 \mathrm{~h}$ light:12 h darkness periods of light cycle and fed once a day. Fish were anesthetized with $150 \mathrm{mg} / \mathrm{l}$ tricaine methanesulfonate (MS-222, Sigma-Aldrich) in tank water and killed by rapid cervical transection. In all experiments, adequate measures were taken to minimize pain or discomfort, and animals were handled according to the guidelines of the European Communities Council directive of 24 November 1986 (86/609/EEC) and to the current Spanish legislation for the use and care of animals RD 1201/2005 (BOE 252/34367-91, 2005).

\section{Cloning, sequence, and phylogenetic analysis}

To clone the $d r N O P$ gene, we have followed the standard methodology previously described (Barrallo et al. 1998, Pinal-Seoane et al. 2006). Oligonucleotides were designed using the Oligo 4.05 Primer Analysis Software (National Biosciences, Inc., Plymouth, MN, USA), DNA sequences were analyzed with Chromas 2.3 (School of Health Science, Griffith University, Australia) software and compared with other nucleotide and/or protein sequence databases using the FASTA or BLAST programs from EMBL and from the NCBI websites (http://www.ebi.ac.uk/embl/ and http://www.ncbi. nlm.nih.gov/ respectively). Protein analysis and structure prediction were performed with the SMART server (http://smart.embl-heidelberg.de).

The retrieved DNA and protein sequences were aligned with the ClustalW program, setting all the parameters as default (Thompson et al. 1994). The obtained multiple sequence alignments were then used to construct a neighbor-joining (NJ) tree with Molecular Evolutionary Genetics Analysis (MEGA4.0.2) software (Tamura et al. 2007) to analyze $P$-distance (calculating the proportion of amino acid differences) with the following parameters: complete deletion and considering a bootstrap value of 1000 replicates. The other settings were given as default by the program. The NJ method has a high degree of accuracy, and it has been previously used to perform the phylogenetic analysis of MOR genes (Herrero-Turrion \& Rodriguez 2008). 


\section{Quantitative reverse transcription real-time PCR}

Total RNA from whole embryos was extracted using Trizol Reagent (Invitrogen Corporation) following the protocol recommended by the manufacturers. cDNA synthesis was carried out by reverse transcription (RT) of total RNA to cDNA using the Promega Corporation RT kit following the manufacturer's protocol. The cDNA samples were then treated with RNAse A $(50 \mathrm{ng} / \mu \mathrm{l})$ during $10 \mathrm{~min}$ at $65^{\circ} \mathrm{C}$ to avoid RNA contamination of the sample. As cDNA is a DNA-RNA double-stranded hybrid, the RNAse A does not act on these molecules. The RNAse A was then precipitated using $8 \mu \mathrm{l}$ of $7.5 \mathrm{M}$ ammonium acetate $(30 \mathrm{~min}$ incubation at $4{ }^{\circ} \mathrm{C}$ and spin at $17400 \mathrm{~g}$ for $30 \mathrm{~min}$ at $4{ }^{\circ} \mathrm{C}$ ). In order to eliminate the impurities of the sample as a consequence of these treatments, cDNA was precipitated with $0.5 \mathrm{ml}$ cold absolute ethanol (30 min at $-20{ }^{\circ} \mathrm{C}$ ). The ethanol was discarded, and the cDNA pellet was eluted in diethyl pyrocarbonate-treated water.

The quantification of the PCR products was performed using SYBR-Green Power Master Mix (Applied Biosystems Hispania, Alcobendas, Madrid, Spain) as previously described (Sanchez-Simon \& Rodriguez 2008). The amplification of $\beta$-actin on $25 \mathrm{ng}$ of the cDNA used in all the experiments was established as the control of cDNA quality. No significant differences were found in the expression of $\beta$-actin on the different cDNAs from tissues used. The oligonucleotides used to amplify the $N O P$ and $\beta$-actin were: $d r N O P \_F \quad 5^{\prime}$ ccgtctgtcacccggtgaa $3^{\prime}$; drNOP_R $5^{\prime}$ aagatgcactcgatgct $3^{\prime} ; \beta$-actin_F $5^{\prime}$ acgacccagacatcagggag $3^{\prime} ; \beta$-actin_R $5^{\prime}$ cctctcttgctctgagcctca $3^{\prime}$. The ABI Prism 7300 detection system (Applied Biosystems) was used to amplify $d r N O P$ and $\beta$-actin, with the following conditions: $10 \mathrm{~min}$ at $95^{\circ} \mathrm{C}$ followed by 36 cycles of $15 \mathrm{~s}$ at $95^{\circ} \mathrm{C}$ and $1 \mathrm{~min}$ at $55^{\circ} \mathrm{C}$. Three PCR reactions were performed for each sample per plate, and each experiment was repeated three times.

The absolute quantitation was achieved through a standard curve. A basic PCR was carried out to amplify the fragment of the transcript of interest (either drNOP or $\beta$-actin) on zebrafish cDNA with the same pair of primers that were going to be used in the real-time PCR. The fragment was cut from the agarose gel and purified. Serial 1:10 dilutions were made from the purified PCR product, ranging from $10^{2}$ to $10^{-5} \mathrm{ng} / \mu \mathrm{l}$. Four out of these eight points were chosen according to their $C_{\mathrm{t}}$ values, considering that the perfect amplification is obtained when the difference in the $C_{\mathrm{t}}$ values from one dilution to the next is $3 \cdot 3$, which gives a fourpoint straight line that has a slope of $-3 \cdot 3$. The dilutions used in the standard curve of both genes, $d r N O P$ and $\beta$-actin, were $10^{-1}, 10^{-2}, 10^{-3}$, and $10^{-4} \mathrm{ng} / \mu \mathrm{l}$. The number of copies was calculated as previously described (Sanchez-Simon \& Rodriguez 2008).
The RT-qPCR results are expressed as mean \pm s.E.M. In the analysis of gene expression changes, the mean of transcripts for each tissue was compared with the mean of transcripts of the control tissue (brain) using unpaired Student's $t$-test with Welch correction; $P \leq 0 \cdot 05$ was considered statistically significant.

\section{Cell culture and transfection}

A $2.6 \mathrm{~kb}$ long EcoRI-NotI fragment comprising the complete open-reading frame (ORF) of drNOP cDNA was excised from the pZiploc plasmid and ligated into the mammalian expression vector pcDNA3 (Invitrogen). Human embryonic kidney cells (HEK293), obtained from American Type Culture Collection (ATCC CRL-1573, Manassas, VA, USA), were maintained in DMEM supplemented with $10 \%$ (v/v) FCS, $2 \mathrm{mM}$ glutamine, $100 \mathrm{U} / \mathrm{ml}$ penicillin, and $0 \cdot 1 \mathrm{mg} / \mathrm{ml}$ streptomycin (all from Gibco-BRL Life Technology, Inc.), at $37^{\circ} \mathrm{C}$ in humidified atmosphere containing $5 \%$ (v/v) $\mathrm{CO}_{2}$ in a Forma incubator. The cell line was transfected with the pcDNA3-drNOP plasmid using Transfectam reagent (Promega Corp.) according to the manufacturer's instructions. Geneticin (G418, Gibco-BRL Life Technology) was added to a final concentration of $500 \mu \mathrm{g} / \mathrm{ml}$ to obtain cell lines that stably express the $d r N O P$ transcript. Positive colonies were isolated and tested for $d r N O P$ mRNA expression by RT-PCR. These colonies were expanded and grown during 3 months before being used in binding studies.

\section{Membrane preparation}

Stably transfected HEK293 cells expressing $d r N O P$ were grown to $80 \%$ confluence, harvested in $\mathrm{PBS}$ pH $7 \cdot 4$ containing $2 \mathrm{mM}$ EDTA, and collected by centrifugation at $500 \mathrm{~g}$. The cell pellets were frozen at $-80^{\circ} \mathrm{C}$ for at least $1 \mathrm{~h}$ and resuspended in $50 \mathrm{mM}$ Tris-HCl buffer $\mathrm{pH} 7 \cdot 4$ (assay buffer) with protease inhibitors $(0 \cdot 1 \mathrm{mg} / \mathrm{ml}$ bacitracin, $3 \cdot 3 \mu \mathrm{M}$ captopril, and protease inhibitor cocktail, from Sigma-Aldrich). The cell suspensions were homogenized with a PotterElvehjem tissue grinder with teflon pestle in assay buffer, and the homogenates were centrifuged at $2000 \mathrm{~g}$ for $10 \mathrm{~min}$ at $4{ }^{\circ} \mathrm{C}$. The nuclear pellet was homogenized again, centrifuged, and discarded. The two supernatants were combined, homogenized again with the tissue grinder, and the membrane pellet was collected upon centrifugation at $18000 \mathrm{~g}$ for $30 \mathrm{~min}$ at $4{ }^{\circ} \mathrm{C}$. The crude membrane fraction was resuspended in ice-cold assay buffer with protease inhibitors, and protein concentration was determined by Bradford (Bio-Rad Laboratories). 


\section{Saturation-binding assays}

A total of 20-25 $\mu \mathrm{g}$ protein was incubated with different concentrations of the radioligand [Leucyl-3,4,5- ${ }^{3} \mathrm{H}$ ] nociceptin for $1 \mathrm{~h}$ at $25^{\circ} \mathrm{C}$ in a final volume of $250 \mu \mathrm{l}$ of assay buffer with $(0 \cdot 1 \mathrm{mg} / \mathrm{ml})$ proteinase-free BSA to avoid the adsorption of the radioligand to the walls of the tubes. A total of $2 \mu \mathrm{M} \mathrm{N} / \mathrm{OFQ}$ was used to determine nonspecific binding. After incubation, the reaction was stopped by adding $4 \mathrm{ml}$ of ice-cold $50 \mathrm{mM}$ Tris-HCl buffer $\mathrm{pH} 7 \cdot 4$; the mixture was rapidly filtrated using a Brandel Cell Harvester and washed two times with GF/B glass fiber filters that were presoaked with $0 \cdot 2 \%(\mathrm{v} / \mathrm{v})$ polyethylenimine for at least $1 \mathrm{~h}$. The filters were placed in scintillation vials and incubated overnight at room temperature in EcoScint A scintillation liquid (London, UK). Radioactivity was counted using a Beckman Coulter 6500 scintillation counter (Pasadena, CA, USA). All experiments were performed in triplicate and repeated five times.

\section{Competition-binding assays}

The following unlabeled ligands were used: N/OFQ (FGGFTGARKSARKLANQ), mDYN A (1-17) (YGGFLRRIRPKLKWDNQ), drDYN A (1-17) (YGGFMRRIRPKLRWDNQ), Nx, Bre, and nor-BNI. A total of 20-25 $\mu \mathrm{g}$ protein was incubated with different concentrations of unlabeled ligand ranging from $0.3 \mathrm{nM}$ to $10 \mu \mathrm{M}$, and using [ Leucyl-3,4,5- $\left.{ }^{3} \mathrm{H}\right]$ nociceptin as a radioligand (the working concentration was similar to the affinity constant, $\left.K_{\mathrm{d}}\right)$. Reactions were incubated for $1 \mathrm{~h}$ at $25^{\circ} \mathrm{C}$ in a final volume of $250 \mu$ l assay buffer with $0.1 \mathrm{mg} / \mathrm{ml}$ proteinase-free BSA. A total of $10 \mu \mathrm{M}$ $\mathrm{N} / \mathrm{OFQ}$ was used to determine nonspecific binding. Experiments were performed as described in 'Saturation-binding assays'. All experiments were performed in triplicate and repeated three times.

\section{$\left[{ }^{35} \mathrm{~S}\right] \mathrm{GTP} \gamma \mathrm{S}$ stimulation assays}

$\left[{ }^{35} \mathrm{~S}\right] \mathrm{GTP} \gamma \mathrm{S}$ (guanosine- $5^{\prime}$-[ $\gamma$-thio $]$ triphosphate)-binding assays were conducted as previously described (Befort et al. 1996). Briefly, $20 \mu \mathrm{g}$ protein was incubated in a $50 \mathrm{mM}$ Tris-HCl pH $7 \cdot 4$ buffer with $100 \mathrm{mM} \mathrm{NaCl}$, $5 \mathrm{mM} \mathrm{MgCl} 2,1 \mathrm{mM}$ EDTA, $1 \mathrm{mM}$ dithiothreitol (DTT), $0 \cdot 1 \%(\mathrm{v} / \mathrm{v})$ BSA, $10 \mu \mathrm{M}$ GDP, and $0 \cdot 1 \mathrm{nM}\left[{ }^{35} \mathrm{~S}\right] \mathrm{GTP} \gamma \mathrm{S}$ in the presence of varying concentrations of activating ligands, ranging from $0 \cdot 1 \mathrm{nM}$ to $10 \mu \mathrm{M}$. The following ligands were used: N/OFQ, mDYN A, and Bre. Reactions were performed in a final volume of $200 \mu \mathrm{l}$ for $1 \mathrm{~h}$ at $30^{\circ} \mathrm{C}$. Nonspecific binding was determined with $10 \mu \mathrm{M}$ unlabeled GTP $\gamma \mathrm{S}$. Bound and free $\left[{ }^{35} \mathrm{~S}\right] \mathrm{GTP} \gamma \mathrm{S}$ were separated by vacuum filtration through GF/B glass fiber filters with a Brandel Cell Harvester as described before. Radioactivity was quantified by liquid scintillation counting. All experiments were performed in triplicate and repeated at least three times.

\section{Data analysis}

Specific binding was defined as the difference between total binding and nonspecific binding (measured in the presence of $2 \mu \mathrm{M}$ for saturation and $10 \mu \mathrm{M} \mathrm{N} / \mathrm{OFQ}$ for competition-binding assays, and in the presence of $10 \mu \mathrm{M}$ unlabeled GTP $\gamma \mathrm{S}$ for $\left[{ }^{35} \mathrm{~S}\right] \mathrm{GTP} \gamma \mathrm{S}$ stimulation assays). Radioligand-binding data were analyzed by computer-assisted nonlinear regression analysis using GraphPad Prism software (San Diego, CA, USA), and $K_{\mathrm{d}}$, receptor density $\left(B_{\max }\right)$, inhibition constant $\left(K_{\mathrm{i}}\right)$, and mean effective dose $\left(\mathrm{EC}_{50}\right)$ were obtained for each ligand. In saturation-binding assays, data were fit either to nonlinear function or to the linear transformation (Scatchard plot: bound/free versus bound). The $K_{\mathrm{i}}$ values were calculated using Cheng and Prusoff's equation, which corrects for the concentration of radioligand used in each experiment as well as for the affinity of the radioligand for its binding site $\left(K_{\mathrm{d}}\right.$; Cheng $\&$ Prusoff 1973). In all cases, data were fit to the one-site or two-site binding model, and compared by using the nonlinear least-squares curve fitting, which is based upon a statistical F-test. $\left[{ }^{35} \mathrm{~S}\right] \mathrm{GTP} \gamma \mathrm{S}$ stimulation results were fitted to a sigmoidal dose-response curve using the Prism program.

\section{Results}

\section{Molecular characterization of drNOP}

A full-length cDNA of $2569 \mathrm{bp}$, named $d r N O P$ (GenBank accession no. AY148348), was cloned (Fig. 1). Sequence analysis of this cDNA shows an ORF of 363 residues (predicted molecular weight of $40.87 \mathrm{kDa})$, which is similar to the length of other NOPs (361-370 amino acids). Protein analysis reveals that drNOP shares the common features with other members of the GPCR superfamily (Fig. 1): seven putative transmembrane domains (TM), four consensus sequences for $N$-glycosylation sites $\left(\mathrm{Asn}^{5}, \mathrm{Asn}^{20}, \mathrm{Asn}^{27}\right.$, and $\mathrm{Asn}^{32}$ ) in the N-terminal extracellular domain, two conserved Cys residues $\left(\mathrm{Cys}^{115}\right.$ and $\mathrm{Cys}{ }^{193}$ ) that can form a disulfide bond between the first and second extracellular loops (ELs), six putative phosphorylation sites on Ser or Thr residues $\left(\operatorname{Ser}^{237}\right.$, Ser $^{242}$, Ser $^{244}$, and Thr ${ }^{255}$ in the third intracellular loop (IL3) and Ser ${ }^{339}$ and Thr ${ }^{346}$ in the C-terminal domain), and two potential palmitoylation sites on Cys residues ( $\mathrm{Cys}^{322}$ and $\mathrm{Cys}^{327}$ ) in the C-terminal domain.

Using the BLASTn program in the ENSEMBL web server (http://www.ensembl.org/), the chromosomal 


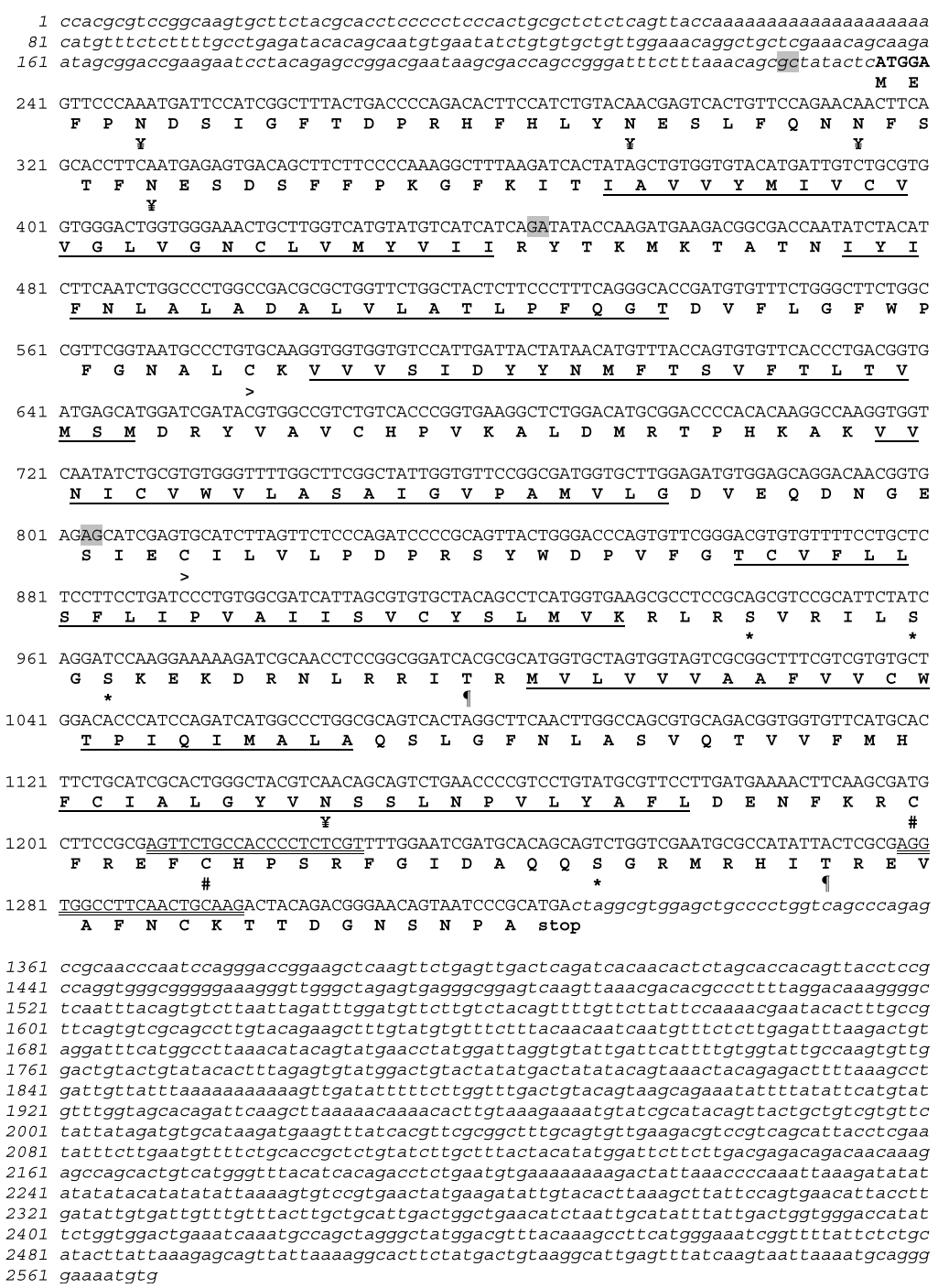

1361 ccgcaacccaatcCagggacCggaagctcagattctgagttgactcagatcacaacact ctagcaccacagttacctccg 1441 ccaggtgggcgggggaaagggttgggctagagtgagggcggagtcaagttaaacgacacgcccttt taggacaaaggggc 1521 tcaatttacagtgtct taattagatttggatgttcttgtctacagttttgttcttattccaaaacgaatacacttgccg 1601 ttcagtgtcgcagccttgtacagaagctttgtatgtgtttct tracaacaatcaatgtt ctct gagatt taagactgt 1681 aggatttcatggccttaacatacagtatgaacctatggattaggtgtattgattcattttgtggtattgccaagtgttg 1761 gactgtactgtatacactt tagagtgtatggactgtactatatgactatatacagtaaactacagagacttt taaagcct 1841 gattgttatttaaaaaaaaagttgatattttcttggtttgactgtacagtaagcagaaatatttatattcatgtat 2001 tattatagatgtgcataagatgaagtttatcacgttcgcggctttgcagtgttgaagacgtccgtcagcattacctcgaa 2081 tatt $c t$ tgaatgtttctgcaccgctctgtatcttgctttactacatatggattcttcttgacgagacagacaacaaag 2161 agccagcactgtcatgggtttacatcacagacctctgaatgtgaaaaaaagactattaaacccaaat taagatatat 2241 atatatacatatatattaaagtgtccgtgaactatgaagatattgtacacttaagct attccagtgaacattacct 2401 tctggtggactgaatcaaatgccagctagggctatggacgtttacaaagcctcatgggaaatcggtttattctctgc 2561 gaaaatgtg

Figure 1 Nucleotide and predicted amino acid sequences of drNOP. Nucleotides are numbered in the $5^{\prime}-3^{\prime}$ direction, and the residues are shown in one-letter code below the nucleotide sequence. The seven transmembrane domains (TM) are single underlined, the exon-intron boundaries are shaded in gray, and the oligonucleotide sequences used in RT-qPCR experiments are double underlined. (*) Ser and (đ) Thr phosphorylation sites (4/2); (¥) N-glycosylation sites (4) at the $\mathrm{N}$-terminus; (\#) putative palmitoylation sites in Cys at the C-terminus; and ( $>$ ) disulfide bond between Cys located at the extracellular loops (EL1 and EL2) respectively.

location of $d r N O P$ gene was assessed in the $\mathrm{Zv} 9$ zebrafish genomic assembly. The $d r N O P$ gene was mapped to 89039 bp fragment (6024852-6113891) in chromosome 23, which comprises the NW_001878401 genomic clone. As also shown in Fig. 1, the $d r N O P$ gene is formed in four exons: the first exon is noncoding (227 bp), the second one contains $8 \mathrm{bp}$ of the $5^{\prime}$-untranslated region (UTR) and $209 \mathrm{bp}$ of the coding sequence $\left(\mathrm{Met}^{1}-\mathrm{Arg}^{70}\right)$, the third exon is $358 \mathrm{bp}$ long $\left(\mathrm{Arg}^{70}\right.$ $\mathrm{Ser}^{190}$ ), and the fourth exon contains the last $526 \mathrm{bp}$ of the ORF (Ser ${ }^{190}$-STOP) and the 1245 bp long $3^{\prime}$-UTR.

\section{Phylogenetic analysis}

drNOP protein sequence was aligned to the annotated NOP -orthologs- and opioid $(\mu, \delta$, and $\kappa)$-paralogsprotein sequences that were retrieved from public databases (Fig. 2). Then, using the NJ method, a phylogenetic tree was created from the multiple sequence alignment (Fig. 3). Four major clusters are evident for NOPs, KORs, DORs, and MORs, which are supported by bootstrap values of 100, 100, 99, and $100 \%$ respectively. In addition to this, no significant 
N-terminal

TM1

IL1 $\Delta \Delta \Delta \quad$ TM2

EL1

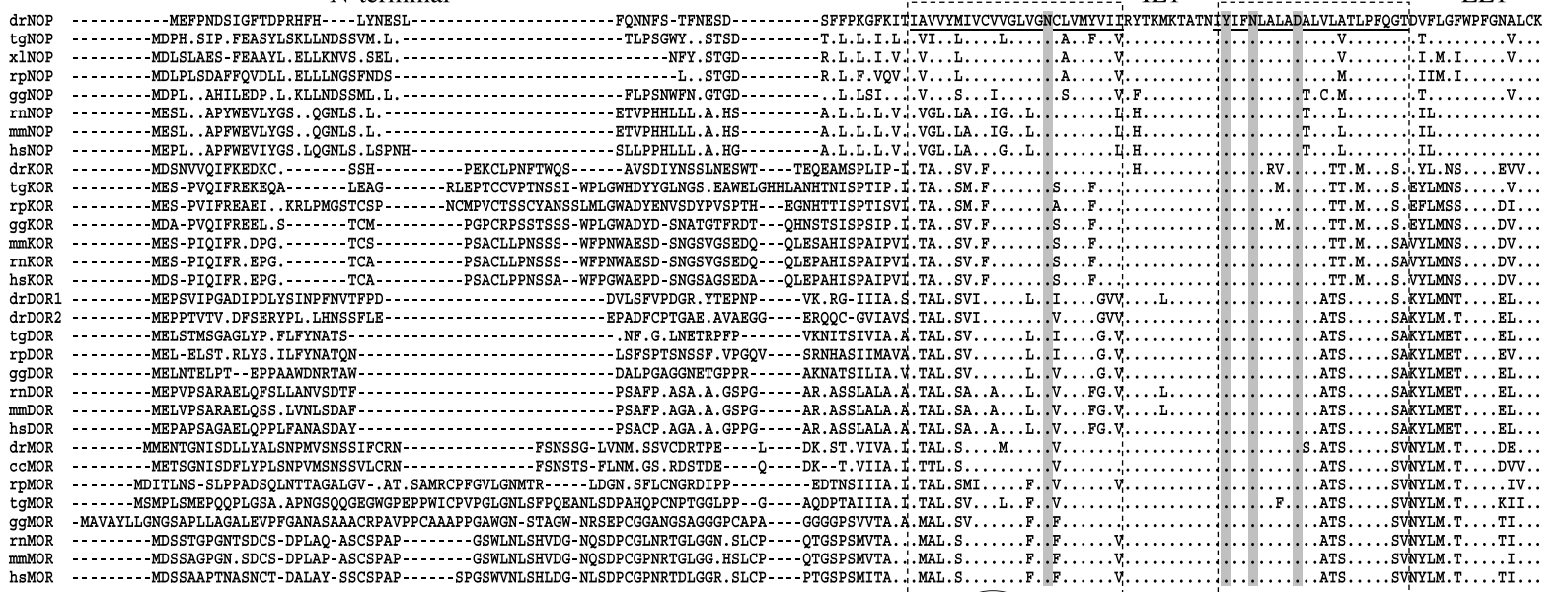

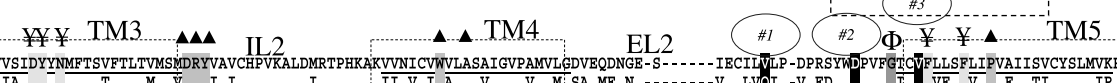

IL3 TM6

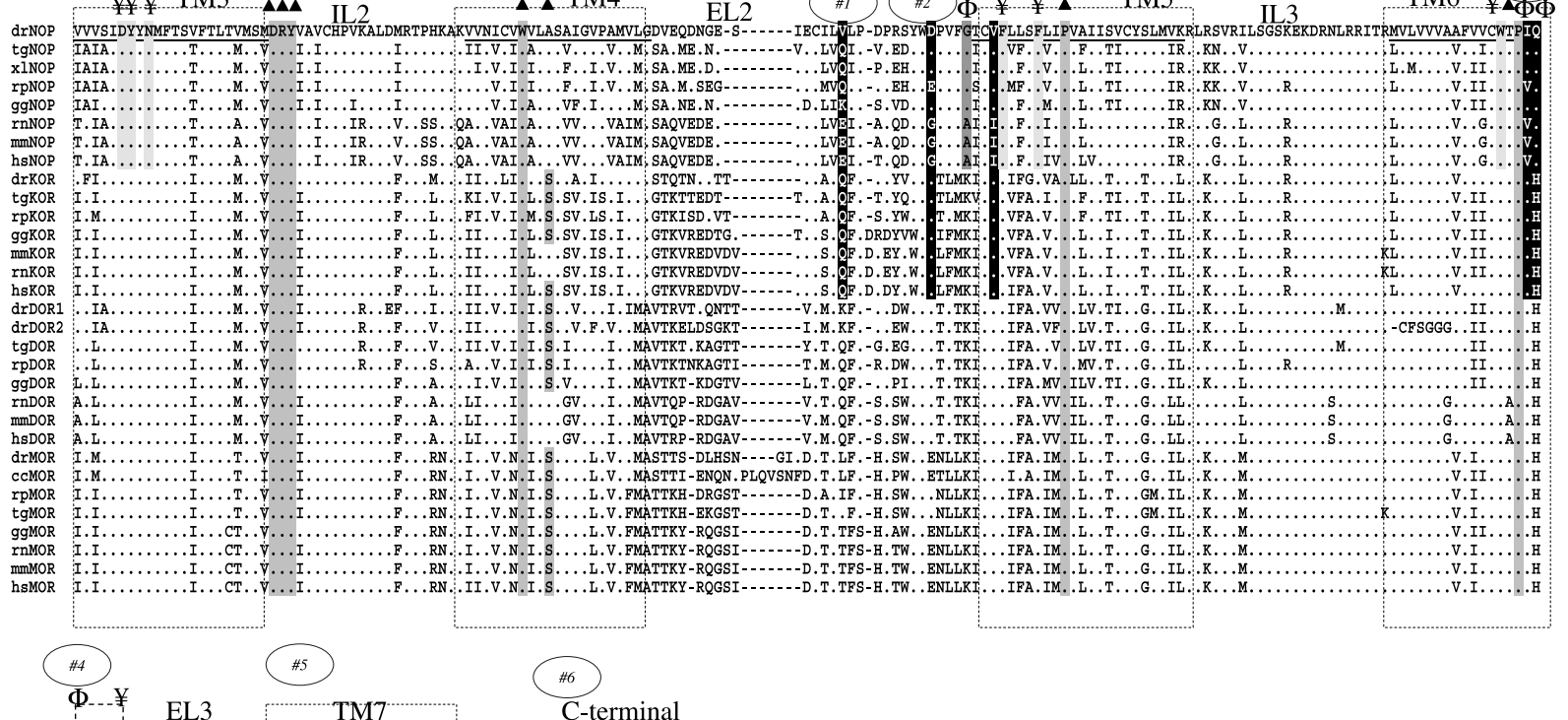

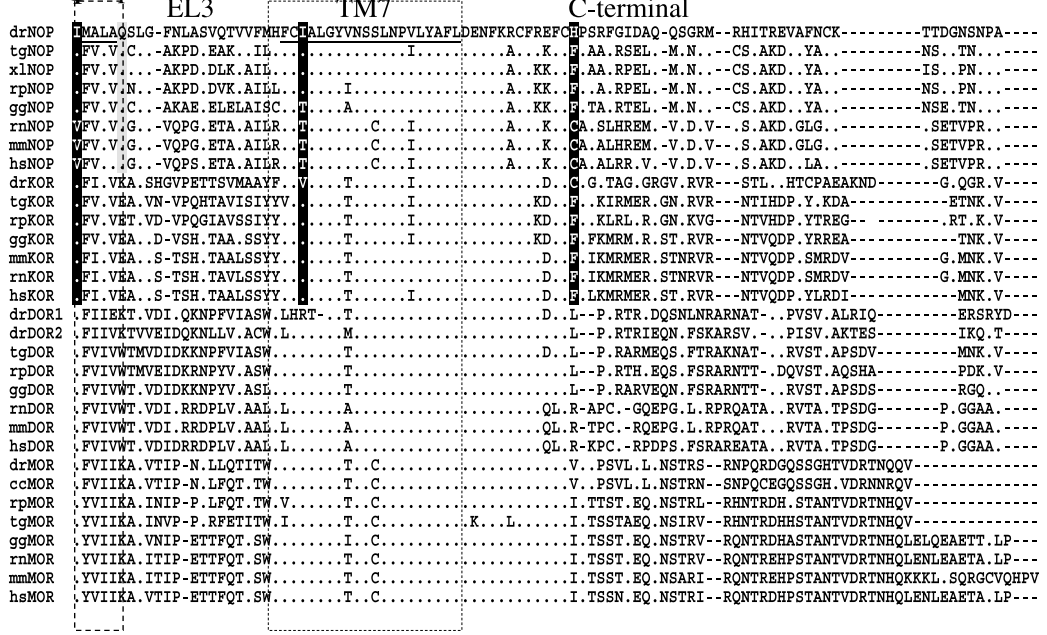


differences were found when the trees were constructed with the nucleotide instead of the amino acid sequences (data not shown). Our findings clearly show that drNOP is indeed a NOP ortholog.

\section{Expression analysis of drNOP mRNA}

The $d r N O P$ gene expression in different tissues from adult zebrafish was analyzed by direct quantification of the number of $d r N O P$ transcripts using RT-qPCR techniques (Fig. 4). drNOP is expressed at high levels in brain, pituitary gland, and intestine (more than $\sim 3.5 \times 10^{5}$ copies per $25 \mathrm{ng} \mathrm{cDNA}$ ), as compared with gills, muscle, and liver (less than $\sim 4 \times 10^{4}$ copies). Furthermore, low gene expression of $d r N O P$ was observed in the heart ( $\sim 1300$ copies $)$.

\section{Saturation-binding assays of [Leucyl-3,4,5- $\left.{ }^{3} \mathrm{H}\right]$ nociceptin}

To determine whether drNOP binds the N/OFQ peptide, the crude membrane fraction of HEK293 cells stably expressing drNOP was used to perform saturationbinding assays with $\left[\right.$ Leucyl-3,4,5- $\left.{ }^{3} \mathrm{H}\right]$ nociceptin. Nonspecific binding was determined in the presence of $2 \mu \mathrm{M}$ unlabeled N/OFQ. As it can be observed in Fig. 5, radiolabeled N/OFQ displays one single binding site in drNOP with a $K_{\mathrm{d}}$ of $0 \cdot 20 \pm 0 \cdot 02 \mathrm{nM}$ and a $B_{\max }$ of $1703 \pm 81 \mathrm{fmol} / \mathrm{mg}$ protein. The Scatchard transformation also confirms the presence of one single binding site for $\mathrm{N} / \mathrm{OFQ}$ on this receptor (Fig. 5, inset). As a negative control, the crude membrane fraction of untransfected HEK293 cells was tested in saturationbinding experiments with $\left[\right.$ Leucyl $\left.-3,4,5-^{3} \mathrm{H}\right]$ nociceptin; as expected, no specific binding was observed.

\section{Competition-binding assays using opioid ligands on drNOP}

Competition-binding experiments with [Leucyl$\left.3,4,5-{ }^{3} \mathrm{H}\right]$ nociceptin were carried out to establish whether opioid ligands were able to bind to drNOP and thus to displace the bound N/OFQ. Nonspecific binding was determined in the presence of $10 \mu \mathrm{M}$ unlabeled N/OFQ. Besides, a homologous displacement with $\mathrm{N} / \mathrm{OFQ}$ was performed in parallel as a positive control. All tested ligands displaced [Leucyl$\left.3,4,5-{ }^{3} \mathrm{H}\right]$ nociceptin binding, yet with different affinities (Fig. 6), and in all cases, the experimental data fitted better to the one-site displacement model. Interestingly, drDYN A showed higher affinity for drNOP than N/OFQ itself, whereas the mDYN A peptide, the $\kappa$-selective antagonist nor-BNI, and the non-selective ligand Bre competed efficiently, albeit with reduced affinity when compared with $\mathrm{N} / \mathrm{OFQ}$. The affinity of $\mathrm{Nx}$ was two rank orders lower than the $K_{\mathrm{i}}$ value obtained for $\mathrm{N} / \mathrm{OFQ}$. Besides, $\mathrm{Nx}$ leaves some residual $\left[\right.$ Leucyl $\left.-3,4,5-{ }^{3} \mathrm{H}\right]$ nociceptin binding that could not be effectively displaced even at the highest concentration (maximal displacement, as determined in the presence of $10 \mu \mathrm{M} \mathrm{Nx}$ of $79 \cdot 15 \pm 2 \cdot 75 \%$ ).

\section{$\operatorname{GTP}_{\gamma}$ S-binding assay}

To determine whether drNOP is functionally coupled to the heterotrimeric $\mathrm{G}$ proteins, $\left[{ }^{35} \mathrm{~S}\right] \mathrm{GTP} \gamma \mathrm{S}$ stimulation analysis was performed using $\mathrm{N} / \mathrm{OFQ}$ as well as using opioid ligands. As shown in the Fig. 7, N/OFQ itself was able to stimulate $\left[{ }^{35} \mathrm{~S}\right] \mathrm{GTP} \gamma \mathrm{S}$ binding with a $\mathrm{EC}_{50}$ of $87 \cdot 84 \pm 18 \cdot 61 \mathrm{nM}$ and a percentage of maximal stimulation of $85 \cdot 69 \pm 7 \cdot 21 \%$. The opioid ligands mDYN $A$ and Bre show $\mathrm{EC}_{50}$ values in the nanomolar range, but they could only activate G-protein coupling up to $55 \%$, thus behaving as partial agonists.

\section{Discussion}

We have cloned and characterized a NOP from zebrafish (drNOP), which displays a high degree of sequence identity to other vertebrate NOPs cloned so far: $58-59 \%$ sequence identity to mammalian NOPs (Nishi et al. 1993, Fukuda et al. 1994, Mollereau et al. 1994, Lachowicz et al. 1995, Pan et al. 1996, Osinski et al. 1999 ) and $64 \%$ sequence identity to amphibian NOPs

Figure 2 ClustalW Multiple Sequence Alignment of NOP and opioid receptor (KOR, DOR, and MOR) sequences. The amino acid sequences from the following species were used: (I) Teleosts: zebrafish (drKOR, NM_182886.1; drDOR1, NM_131258.3; drDOR2, NM_212755.1; and drMOR, NM_131707) and Catostomus commersoni, white sucker (ccMOR, Y10904). (II) Amphibians: Taricha granulosa, rough-skinned newt (tgNOP, AY728087; tgKOR, AY725197.1; tgDOR, AY751785.1; and tgMOR, AY751784), Xenopus laevis, African clawed frog (xINOP, AY7244474), and Rana pipiens, northern leopard frog (rpNOP, AY434690; rpKOR, AF530573.2; rpDOR, AF530572.1; and rpMOR, AF530571). (III) Birds: Gallus gallus, chicken (ggNOP, XM_417424.2; ggKOR, XM_426087.2; ggDOR, XM_427506.2; and ggMOR (Herrero-Turrion \& Rodriguez 2008). (IV) Mammals: Rattus norvegicus, rat (rnNOP, NM_031569.2; rnKOR, NM_017167.2; rnDOR, NM_012617.1; and rnMOR, NM_013071), Mus musculus, mouse (mmNOP, AK079529; mmKOR, NM_011011.1; mmDOR, NM_013622.3; and mmMOR, NM_011013), and Homo sapiens, human (hsNOP, NM_000913.3; hsKOR, NM_000912.3; hsDOR, NM_000911.3; and hsMOR, NM_000914.2). Transmembrane domains are boxed, and intracellular/extracellular loops and $\mathrm{N}$-/C-terminal domains are also indicated. Filled triangles, highly conserved residues in GCPR superfamily; $¥$, NOP residues known to influence ligand-binding affinity; $\Phi$, amino acids which are involved in $\kappa$-ligand recognition; dots, identical residues to drNOP; dashes, sequence gaps. For further details about the importance of those amino acid residues which are shaded (from \#1 up to \#6), please refer to Table 1. TM, transmembrane domain; IL, intracellular loop; EL, extracellular loop. 


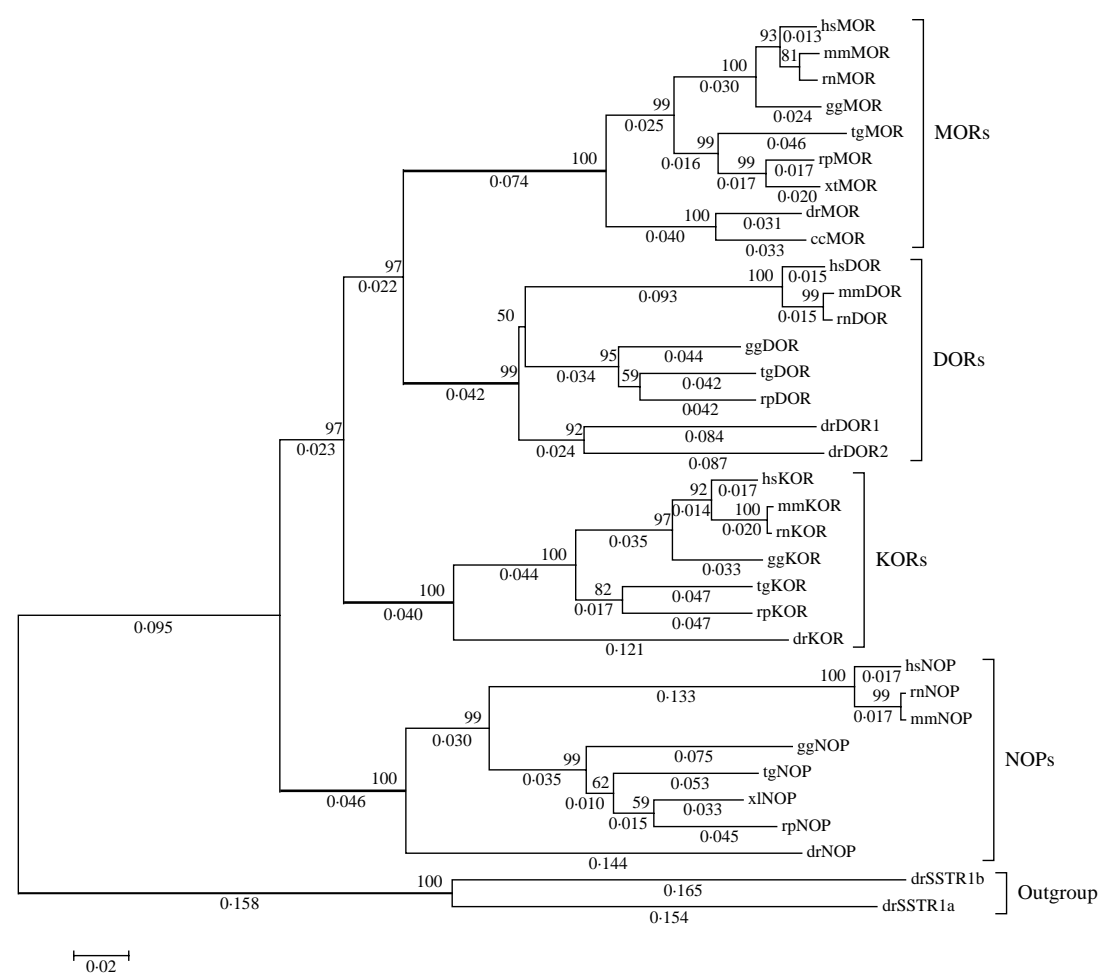

Figure 3 Phylogenetic analysis generated by the NJ method using MEGA4 (Tamura et al. 2007) from the multiple sequence alignment shown in Fig. 2. Whole numbers indicate bootstrap values of 1000 replicates, and branch distances are given in decimal numbers when $>50 \%$. Two zebrafish somatostatin receptors (drSSTR1a and drSSTR1b, XM_691574 and XM_680740) were used as an outgroup.

(Walthers et al. 2005, Stevens et al. 2007). On the other hand, the degree of homology to opioid receptors, either from zebrafish (drMOR, drDOR, and drKOR) or from other vertebrates, only reaches $50-55 \%$. In general, the highest level of sequence identity between the different NOP and opioid receptors is found at the TMs and ILs, whereas the N-terminus, EL2-3, and the C-terminus are the most divergent (Waldhoer et al. 2004).

The number of exons that contain the entire coding region of $d r N O P$ (3) and their lengths are relatively similar to those described in other vertebrates (Nishi et al. 1993, Bunzow et al. 1994, Chen et al. 1994, Fukuda et al. 1994, Mollereau et al. 1994, Wang et al. 1994, Wick et al. 1994, Lachowicz et al. 1995, Pan et al. 1996, Osinski et al. 1999, Walthers et al. 2005, Stevens et al. 2007), whereas the introns of $d r N O P$, which have variable lengths, are longer than introns of other mammalian NOPs (Pan et al. 1996).

Using the NJ method, a phylogenetic tree was constructed with the aligned amino acid sequences from NOPs and opioid receptors (MORs, DORs, and KORs) from different vertebrates (Fig. 3). Somatostatin receptors of zebrafish (drSSTR1a and drSSTR1b), which are paralogs of the opioid receptors, were used as the outgroup. drNOP is aligned in the same clade as the rest of vertebrate NOPs; hence, this new cDNA/ protein corresponds to a NOP ortholog in zebrafish. In particular, NOP sequences are positioned basal to the rest of the clades of opioid receptors, and NOP is the most divergent clade of the opioid/orphanin receptor family.

RT-qPCR gene expression analysis indicates that $d r N O P$ mRNA is highly expressed in the CNS (brain and pituitary gland). Previous studies have reported the expression of $P N O C$ gene in zebrafish brain (Gonzalez-Nunez et al. 2003), and high NOP densities in the rat CNS (Mollereau \& Mouledous 2000) and in the amphibian (rough-skinned newt) brain (Walthers et al. 2005). We also detect high gene expression of $d r N O P$ in the intestine, which is similar to expression of NOP in the rat small intestine (Wang et al. 1994). In relation to this, similar results were also reported by Gonzalez-Nunez et al. (2003) for $d r P N O C$. On the other hand, lower gene expression levels of $d r N O P$ mRNAs were detected in other peripheral tissues. The presence of drNOP in gills might depict NOP expression in the lungs of the tetrapodian rough-skinned newt (Walthers et al. 2005) and mammals (Rizzi et al. 1999). The fact that low expression levels of $d r N O P$ mRNA were found 


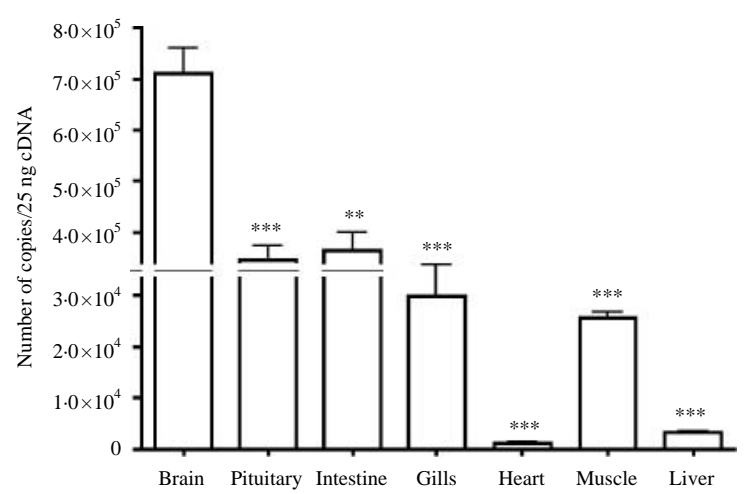

\begin{tabular}{|c|c|c|c|c|c|c|c|}
\hline & Brain & Pituitary & Intestine & Gills & Heart & Muscle & Liver \\
\hline $\begin{array}{c}\text { No. of Copies / } \\
\text { 25 ng cDNA }\end{array}$ & $\begin{array}{c}71478 \pm \\
49972\end{array}$ & $\begin{array}{c}344335 \pm \\
27323\end{array}$ & $\begin{array}{c}364286 \pm \\
36509\end{array}$ & $33913 \pm$ & $1281 \pm$ & $29253 \pm$ & $3733 \pm$ \\
\end{tabular}

Figure 4 Absolute quantification of drNOP expression by RT-qPCR in adult tissues. Bars (mean \pm s.E.m.) represent the number of mRNA copies of drNOP mRNA in each adult tissue. Zebrafish $\beta$-actin was used as a housekeeping gene. For each tissue, the number of experiments represented in this graph was between four and six; ${ }^{\star \star} P \leq 0.005 ;{ }^{* \star} P \leq 0.001$ (unpaired Student's $t$-test with Welch correction).

in the heart is in accordance with the existence of high-affinity $\left[{ }^{3} \mathrm{H}\right] \mathrm{N} / \mathrm{OFQ}$-binding sites on rat heart (Dumont \& Lemaire 1998). Furthermore, it is the first time that NOP expression has been found in muscle and liver cells, although its role in these organs has not been determined yet.

Binding studies allowed us to determine the pharmacological profile of drNOP. Saturation-binding analyses have revealed that $\left[\right.$ Leucyl-3,4,5- $\left.{ }^{3} \mathrm{H}\right]$ nociceptin binds to drNOP with relatively high affinity. The affinity constant $\left(K_{\mathrm{d}}=0 \cdot 20 \pm 0 \cdot 02 \mathrm{nM}\right)$ of this single binding site is in the same range as those reported for mammalian NOPs $\left(K_{\mathrm{d}}=0 \cdot 10-0 \cdot 20 \mathrm{nM}\right.$; Meng et al. 1996, Mollereau et al. 1996, Butour et al. 1997, Hashiba et al. 2002) and for the rough-skinned newt NOP $\left(K_{\mathrm{d}}=0.20 \mathrm{nM}\right.$; Walthers et al. 2005). These results indicate that drNOP affinity for $\mathrm{N} / \mathrm{OFQ}$ is conserved throughout the evolutionary scale.

Competition-binding experiments indicated that [Leucyl-3,4,5- $\left.{ }^{3} \mathrm{H}\right]$ nociceptin binding is displaced by $\mathrm{N} / \mathrm{OFQ}$ as well as by opioid ligands. Remarkably, the $K_{\mathrm{i}}$ value for drDYN A is lower than the one found for $\mathrm{N} / \mathrm{OFQ}$ in homologous competition-binding assays, thus implying that drDYN A binds to drNOC with higher affinity than $\mathrm{N} / \mathrm{OFQ}$ itself. mDYN A, Bre, and nor-BNI competed efficiently ( $K_{\mathrm{i}}$ values on the nanomolar range), whereas $\mathrm{Nx}$ showed reduced affinity for drNOC receptor. A prior study has reported that PDYN-derived peptides displayed relatively high affinity for the rough-skinned newt NOP (Walthers et al. 2005). In contrast, mDYN A (1-17) showed moderate ability to compete in equilibrium binding of $\left[{ }^{3} \mathrm{H}\right]$ nociceptin in a crude membrane fraction from Chinese hamster ovary cells expressing the mammalian NOP (Butour et al. 1997). However, the combination of four-point mutations in the rat NOP yielded a chimeric receptor that binds both N/OFQ and mDYN A (1-17) with subnanomolar affinity (Meng et al. 1996).

To determine whether drNOP was functional, $\left[{ }^{35} \mathrm{~S}\right] \mathrm{GTP} \gamma \mathrm{S}$ stimulation assay was used to evaluate the effect of different agonists to promote G-protein coupling. All ligands tested were able to activate drNOP, yet with different potencies and maximal effects. N/OFQ behaved as a full agonist, displaying nanomolar $\mathrm{EC}_{50}$ values, while opioid ligands could partially activate drNOP, thus acting as partial agonists. In contrast, mDYN A had no effect in inhibiting adenylate cyclase via mammalian NOP (Butour et al. 1997), and to date, no functional results have been reported for amphibian NOPs.

The fact that different NOPs share a common binding profile indicates that the binding pocket is highly conserved among the evolutionary scale. Particularly, five residues within the binding pocket are known to greatly influence ligand affinity: $\operatorname{Asp}^{130}$ and $\mathrm{Tyr}^{131}$ in TM3, Phe ${ }^{220}$ and $\mathrm{Phe}^{224}$ in TM5, and Trp ${ }^{276}$ in TM6 (human hsNOP amino acid numbering; New \& Wong 2002); these residues are well conserved in drNOP. Furthermore, $\mathrm{Asn}^{133}$ in TM3 and $\mathrm{Gln}^{286}$ in TM6, which play a pivotal role in signal transduction (Mouledous et al. 2000, Kam et al. 2002), are also conserved in drNOP (Fig. 2). Furthermore, the hydrophobic cleft between Gly $^{182}$-Gly ${ }^{189}$ in TM4 and Gly ${ }^{212}$-Ile ${ }^{219}$ (EL2 and TM5), which is located within the transmembrane helix bundle and that interacts with $\mathrm{Gly}^{6}$ from N/OFQ (hsNOP amino acid numbering; New \& Wong 2002), is partially conserved in drNOP. However, Gly ${ }^{212}$, which is present in all mammalian NOPs, is replaced by Asp in nonmammalian NOPs (e.g. drNOP, Asp ${ }^{205}$ ), KORs, DORs,

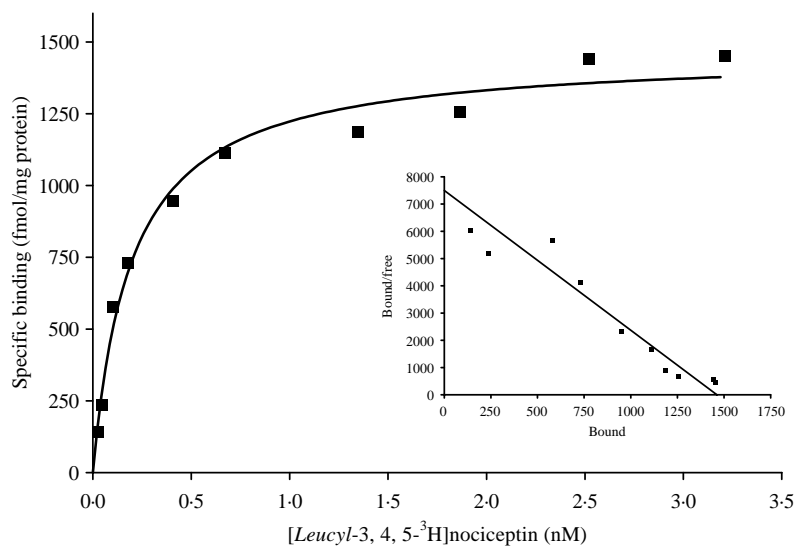

Figure 5 Saturation-binding analysis of [Leucyl-3,4,5- ${ }^{3} \mathrm{H}$ ] nociceptin in membrane homogenates of HEK293 cells stably expressing drNOP. Inset: Scatchard transformation. Data are from a representative experiment that was repeated five times in triplicate. 


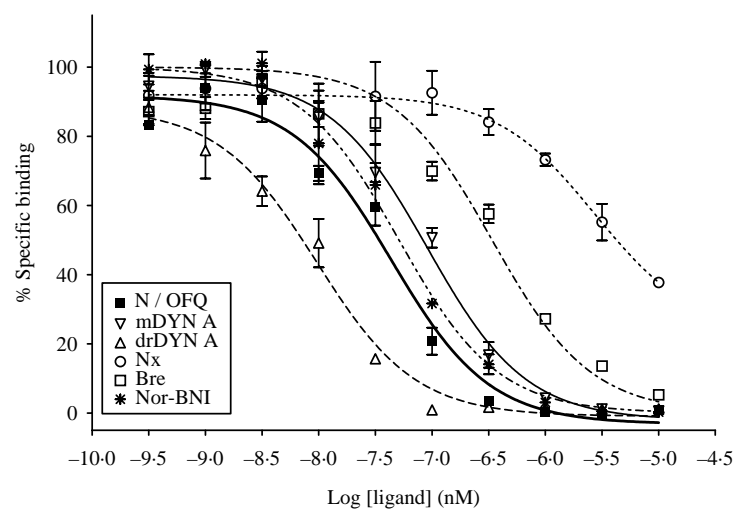

$K_{\mathrm{i}}$ values mean \pm S.E.M $(\mathrm{nM})$ for several ligands obtained from competition binding assays using $\left[\right.$ Leucyl $\left.-3,4,5-{ }^{3} \mathrm{H}\right]$ nociceptin on drORL receptor.

\begin{tabular}{|l|l|l|l|l|l|l|}
\hline Ligand & N/OFQ & mDYN A & drDYN A & Nx & Bre & Nor-BNI \\
\hline$K$ K & $7.99 \pm 1.02$ & $32.04 \pm 9.78$ & $162 \pm 0.47$ & $1086 \pm 177$ & $94.55 \pm 9.78$ & $15.88 \pm 2.25$ \\
\hline
\end{tabular}

\begin{tabular}{|l|l|l|l|l|l|}
\hline & $32.04 \pm 9.78$ & $1.62 \pm 0.47$ & $1086 \pm 177$ & $94.55 \pm 9.78$ & $15.88 \pm 2.25$ \\
\hline
\end{tabular}

Figure 6 Competition-binding experiments using [Leucyl$\left.3,4,5-{ }^{3} \mathrm{H}\right]$ nociceptin on drNOP membrane homogenates.

Relative abilities of N/OFQ and opioid ligands to compete with equilibrium binding of radiolabeled N/OFQ. Data were fit to the one-site competition model, and each point represents the mean \pm S.E.M. (capped bars) of three independent experiments performed in triplicate. The table summarizes the $K_{\mathrm{i}}$ values (mean \pm S.E.M., $\mathrm{nM}$ ) for several ligands obtained from this competition-binding assay.

and amphibian MORs, and by Glu in the northern leopard frog NOP (rpNOP) and teleost and mammalian MORs. These amino acid substitutions might explain why mammalian NOPs display reduced affinity for DYN A, whereas non-mammalian NOPs are able to bind PDYN-derived peptides with (sub)nanomolar affinities.

The different pharmacological profiles observed for zebrafish and mammalian NOPs could be explained by the existence of amino acid changes in the protein sequences, most of them located in the ELs. Besides, both NOP and KOR discriminate between their corresponding ligands through a general pattern of attractions and repulsions, which is based on the secondary structure of the ELs (Meng et al. 1996). The degree of sequence identity at the EL1 between drNOP and mammalian NOP is $87 \%$ and between $\mathrm{drNOP}$ and mammalian KOR is $46 \%$. Although it seems that EL1 is not directly involved in ligand recognition and/or specificity, EL2 is thought to play a critical role in N/OFQ binding and receptor activation (Mollereau et al. 1999, Vincent et al. 2008). As shown in Fig. 2, EL2 of drNOP is quite unique, as compared with mammalian NOP and KOR (degree of sequence identity of 36 and $30 \%$ respectively). It has been shown that the negative charges in EL2 are essential for ligandreceptor interaction (Reinscheid et al. 1996, Dooley \& Houghten 2000). In this line, although the sequence $\mathrm{Glu}^{194}$-Asp-Glu-Glu ${ }^{197}$ does not have a direct role in agonist binding per se, it maintains the mammalian NOP in its active conformation after agonist binding
(Mouledous et al. 2000). In the case of drNOP, although the degree of sequence identity in EL2 is relatively low, the number of acidic residues is conserved, yet these amino acids are more spread across the EL2 domain. Finally, the degree of sequence identity of EL3 between drNOP and mammalian NOP and KOR is fairly low (35 and $21 \%$ respectively); however, some residues known to play a critical role in receptor activation are conserved among NOPs, as it is the case of $\mathrm{Gln}^{286}$ in mammalian NOP (Gln ${ }^{279}$ in drNOP) (Fig. 2; Mouledous et al. 2000).

Site-directed mutagenesis studies have yielded receptors with both NOP and KOR characteristics (Meng et al. 1996, Mollereau et al. 1996, Meng et al. 1998). Interestingly, in drNOP and other non-mammalian NOPs, some of the amino acids, which are conserved in other NOPs, are replaced by prototypical $\kappa$ residues which are involved in $\kappa$-ligand recognition (Table 1). For example, the mutation Thr to Ile in the rat NOP increases the affinity for mDYN A in 20-fold (Meng et al. 1996). In this case, non-mammalian NOP contains an Ile in the homologous position (\#5 in Table 1 and Fig. 2). Additionally, the four-point mutations Val-Gln-Val to Ile-His-Ile (in TM6-EL3) and Thr to Ile (in EL3-TM7) in the rat NOP yielded a dual receptor, as it binds N/OFQ with the same affinity as the wild-type receptor, but it also recognizes opioid ligands (Meng et al. 1996). In fact, this mutant receptor displays

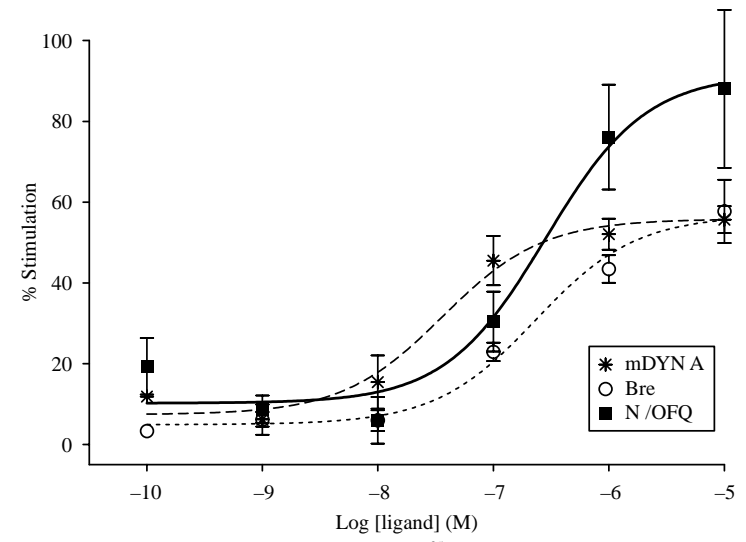

$\mathrm{EC}_{50}$ values for several ligands obtained from $\left[{ }^{35} \mathrm{~S}\right] \mathrm{GTP} \gamma \mathrm{S}$ stimulation assays on drNOP receptor.

\begin{tabular}{|c|c|c|c|}
\hline Ligand & N/OFQ & mDYN A & Bre \\
\hline EC $_{50}$ (nM) & $87.84 \pm 18 \cdot 61$ & $47.47 \pm 30 \cdot 76$ & $283 \cdot 20 \pm 119 \cdot 70$ \\
\% Max. Stim.* & $85.69 \pm 7.21 \%$ & $55.63 \pm 2.49 \%$ & $54.17 \pm 3 \cdot 21 \%$ \\
\hline
\end{tabular}

* Percentage of maximal $\left[{ }^{35} \mathrm{~S}\right] \mathrm{GTP} \gamma \mathrm{S}$ stimulation shown at a concentration of $10 \mu \mathrm{M}$ of the activating ligand.

Figure $7\left[{ }^{35} \mathrm{~S}\right] \mathrm{GTP} \gamma \mathrm{S}$ stimulation assays on drNOP. Relative abilities of nociceptin and opioid ligands to promote G-protein coupling and $\left[{ }^{35} \mathrm{~S}\right] \mathrm{GTP} \gamma \mathrm{S}$ binding in crude membrane fraction of HEK293 (drNOP). Data points represent the mean \pm S.E.M. (capped bars) of three different experiments performed in duplicate. The table summarizes the $\mathrm{EC}_{50}$ values obtained for several ligands obtained from this $\left.{ }^{35} \mathrm{~S}\right] \mathrm{GTP} \gamma \mathrm{S}$ stimulation assays and the percentage of maximal $\left[{ }^{35} \mathrm{~S}\right] \mathrm{GTP} \gamma \mathrm{S}$ stimulation shown at a concentration of $10 \mu \mathrm{M}$ of the activating ligand. 
Table 1 Amino acid motifs of non-mammalian NOPs, which are not conserved in mammalian NOPs and which are replaced by prototypical $\kappa$ residues $\left({ }^{\star}\right)$; interestingly, these residues are involved in $\kappa$-ligand recognition. For a better understanding of this table, consideration of Fig. 2 is suggested. Moreover, in the analysis of this table the amino acid sequence of the white sturgeon NOP (GenBank accession number GU228526; McClendon et al. 2010) has also been included

\begin{tabular}{|c|c|c|c|c|}
\hline & Domain & $\begin{array}{l}\text { Non-mammalian } \\
\text { NOPs }\end{array}$ & $\begin{array}{l}\text { Mammalian } \\
\text { NOPs }\end{array}$ & KORs \\
\hline$\# 1$ & EL2 & Val/GIn*/Lys & Glu & $\mathrm{Gln}{ }^{\star}$ \\
\hline \#2 & EL2 & Asp*/Glu & Gly & Asp* \\
\hline \#3 & EL2-TM5 & $\mathrm{Val}^{*}$ & Ile & Val $^{*}$ \\
\hline \#4 & TM6-EL3 & $\|\mathrm{e} / \mathrm{Val}-\mathrm{G} \mathrm{ln}-\| \mathrm{e}^{\star}$ & Val-GIn-Val & Val-His-Ile* \\
\hline \#5 & EL3-TM7 & $\| e^{\star}$ & Thr & $\mathrm{Val} / \mathrm{Ile}^{\star}$ \\
\hline \#6 & C-terminal & His/Tyr/Phe* & Cys & Cys/Phe* \\
\hline
\end{tabular}

TM, transmembrane domain; EL, extracellular loop.

increased affinity for PDYN $\kappa$-selective peptides, and the affinity shown for mDYN A (1-17) is in the subnanomolar range (Meng et al. 1996). As shown in Table 1 (\#6 in Table 1 and Fig. 2), non-mammalian NOPs also contain Ile-Gln-Ile (in TM6-EL3) and Ile (in EL3-TM7), as expected in an opioid receptor.

The message-address theory states that opioid peptides can be divided into two clearly distinct domains. The 'message' would be the common structural moiety, which is located at the N-terminus, namely 'Try-Gly-Gly-Phe'; the rest of the peptide would form the 'address' (Chavkin \& Goldstein 1981). The 'message' is where the biological activity of the peptide resides, and hence it binds to the receptor-binding pocket. The 'address' would interact with different domains of the ELs, thus determining the affinity and selectivity of the ligand for a given receptor (Metzger \& Ferguson 1995). Also, it has been suggested that KOR and NOP derived from the same ancestral gene through a series of duplication and divergence events that run in parallel with the evolution of PDYN and PNOC genes (Dores et al. 2002, McClendon et al. 2010). Mollereau et al. (1999) postulated that N/OFQ and DYN A underwent a coordinated inversion of the 'message' and 'address' domains, which rendered selective ligands for KOR and NOP. According to this theory, DYN A will exert its activity through a direct interaction of the N-terminal domain with the receptor, whereas it is not the case for N/OFQ. Mollereau et al. (1999) established that the biological activity of $\mathrm{N} / \mathrm{OFQ}$ resides in the positively charged residues located at the C-terminus, instead of in the hydrophobic $\mathrm{N}$-terminal domain. Therefore, the analysis of the pharmacological profile of NOPs in fishes supports the hypothesis of separate 'message'-'address' domains for the opioid and N/OFQ peptides.

Gonzalez-Nunez et al. (2003) reported that one of the $\mathrm{N} / \mathrm{OFQ}$ peptides from zebrafish, drNOC, is highly similar to $\mathrm{mDYN} A$, and presents the classical 'opioid address' (Tyr-Gly-Gly-Phe) at its N-terminus. We hypothesized that drNOC might bind to opioid receptors with high affinity, and that drNOP will recognize and bind opioid ligands with high affinity too. Besides, it has been reported that white sturgeon PNOC-derived peptides are able to bind to the three mammalian opioid receptors $(\mu, \delta$, and $\kappa)$, as well as to mammalian NOP (Danielson et al. 2001). Besides, competition-binding assays performed with the roughskinned newt NOP have revealed that amphibian NOP binds PDYN-derived peptides with broad affinity, although no significant binding was found for other opiate drugs (Walthers et al. 2005). The latter result is consistent with the fact that highly-selective ligands for the mammalian opioid receptors (e.g. ([D-Ala ${ }^{2}$, $N$-MePhe ${ }^{4}$, Gly ${ }^{5}$-ol] enkephalin) - DAMGO, D-Penicillamine (2,5)-enkephalin - DPDPE or $[(5 \alpha, 7 \alpha, 8 \beta)-(+)-N-$ methyl- $N$-[7-(1-pyrrolidinyl)-1-oxaspiro[4.5] dec-8-yl]benzeneacetamide] -U69,593-) failed to show effective displacement on amphibians and teleosts, such as zebrafish (Gonzalez-Nunez et al. 2006). However, less selective ligands, as Bre or $\mathrm{Nx}$, are able to recognize and displace $\left[{ }^{3} \mathrm{H}\right]$ nociceptin binding on drNOP, which clearly differs from the published reports for amphibian NOPs (Walthers et al. 2005, Stevens et al. 2007).

In conclusion, our results clearly show that drNOP recognizes and binds N/OFQ as well as opioid ligands, showing a preference for the $\kappa$-selective agents. Hence, drNOP might be a potential evolutionary link between NOP and KOR, and will help to bridge the gap between opiate and NOP pharmacology.

\section{Declaration of interest}

The authors declare that there is no conflict of interest that could be perceived as prejudicing the impartiality of the research reported.

\section{Funding}

This work was supported in part by grants from Spanish Ministry of Science and Education (SAF2007-61581) and Junta de Castilla y León (SA037A008). F M S-S is a predoctoral fellow of Junta de Castilla y León.

\section{Acknowledgements}

The authors would like to thank G Valencia and G Arsequell for synthesizing the zebrafish dynorphin A peptide.

\section{References}

Barrallo A, Malvar FG, Gonzalez R, Rodriguez RE \& Traynor JR 1998 Cloning and characterization of a $\delta$ opioid receptor from zebrafish. Biochemical Society Transactions 26 S360. (doi:10.1042/bst026s360) 
Befort K, Tabbara L, Kling D, Maigret B \& Kieffer BL 1996 Role of aromatic transmembrane residues of the delta-opioid receptor in ligand recognition. Journal of Biological Chemistry 271 10161-10168. (doi:10.1074/jbc.271.17.10161)

Bunzow JR, Saez C, Mortrud M, Bouvier C, Williams JT, Low M \& Grandy DK 1994 Molecular cloning and tissue distribution of a putative member of the rat opioid receptor gene family that is not a mu, delta or kappa opioid receptor type. FEBS Letters 347 284-288. (doi:10.1016/0014-5793(94)00561-3)

Butour JL, Moisand C, Mazarguil H, Mollereau C \& Meunier JC 1997 Recognition and activation of the opioid receptor-like ORL 1 receptor by nociceptin, nociceptin analogs and opioids. European Journal of Pharmacology 321 97-103. (doi:10.1016/S0014-2999 (96) 00919-3)

Chavkin C \& Goldstein A 1981 Specific receptor for the opioid peptide dynorphin: structure-activity relationships. PNAS 78 6543-6547. (doi:10.1073/pnas.78.10.6543)

Chen Y, Fan Y, Liu J, Mestek A, Tian M, Kozak CA \& Yu L 1994 Molecular cloning, tissue distribution and chromosomal localization of a novel member of the opioid receptor gene family. FEBS Letters 347 279-283. (doi:10.1016/0014-5793(94)00560-5)

Cheng Y \& Prusoff WH 1973 Relationship between the inhibition constant (K1) and the concentration of inhibitor which causes 50 per cent inhibition (I50) of an enzymatic reaction. Biochemical Pharmacology 22 3099-3108. (doi:10.1016/0006-2952(73)90196-2)

Chiou LC, Liao YY, Fan PC, Kuo PH, Wang CH, Riemer C \& Prinssen EP 2007 Nociceptin/orphanin FQ peptide receptors: pharmacology and clinical implications. Current Drug Targets 8 117-135. (doi:10.2174/138945007779315605)

Danielson PB, Hoversten MT, Fitzpatrick M, Schreck C, Akil H \& Dores RM 2001 Sturgeon orphanin, a molecular "fossil" that bridges the gap between the opioids and orphanin $\mathrm{FQ} /$ nociceptin. Journal of Biological Chemistry 276 22114-22119. (doi:10.1074/jbc. M011741200)

Dooley CT \& Houghten RA 2000 Orphanin FQ/nociceptin receptor binding studies. Peptides 21 949-960. (doi:10.1016/S0196-9781(00) 00231-X)

Dores RM, Lecaude S, Bauer D \& Danielson PB 2002 Analyzing the evolution of the opioid/orphanin gene family. Mass Spectrometry Reviews 21 220-243. (doi:10.1002/mas.10029)

Dumont M \& Lemaire S 1998 Characterization of the high affinity $[3 \mathrm{H}]$ nociceptin binding site in membrane preparations of rat heart: correlations with the non-opioid dynorphin binding site. Journal of Molecular and Cellular Cardiology 30 2751-2760. (doi:10. 1006/jmcc.1998.0838)

Fukuda K, Kato S, Mori K, Nishi M, Takeshima H, Iwabe N, Miyata T, Houtani T \& Sugimoto T 1994 cDNA cloning and regional distribution of a novel member of the opioid receptor family. FEBS Letters 343 42-46. (doi:10.1016/0014-5793(94)80603-9)

Gonzalez-Nunez V \& Rodriguez RE 2009 The zebrafish: a model to study the endogenous mechanisms of pain. ILAR Journal $\mathbf{5 0}$ 373-386.

Gonzalez-Nunez V, Gonzalez-Sarmiento R \& Rodriguez RE 2003 Cloning and characterization of a full-length pronociceptin in zebrafish: evidence of the existence of two different nociceptin sequences in the same precursor. Biochimica et Biophysica Acta 1629 114-118. (doi:10.1016/j.bbaexp.2003.08.001)

Gonzalez-Nunez V, Barrallo A, Traynor JR \& Rodriguez RE 2006 Characterization of opioid-binding sites in zebrafish brain. Journal of Pharmacology and Experimental Therapeutics 316 900-904. (doi:10.1124/jpet.105.093492)

Hashiba E, Lambert DG, Farkas J, Toth G \& Smith G 2002 Comparison of the binding of [(3) H] nociceptin/orphaninFQ(1-13) NH(2), $[(3) \mathrm{H}]$ nociceptin/orphaninFQ(1-17) OH and [(125) I] Tyr(14) nociceptin/orphaninFQ(1-17)OH to recombinant human and native rat cerebrocortical nociceptin/orphanin FQ receptors. Neuroscience Letters 328 5-8. (doi:10.1016/S0304-3940(02)00259-8)
Herrero-Turrion MJ \& Rodriguez RE 2008 Bioinformatic analysis of the origin, sequence and diversification of mu opioid receptors in vertebrates. Molecular Phylogenetics and Evolution 49 877-892. (doi:10.1016/j.ympev.2008.09.016)

Kam KW, New DC \& Wong YH 2002 Constitutive activation of the opioid receptor-like (ORL1) receptor by mutation of Asn133 to tryptophan in the third transmembrane region. Journal of Neurochemistry 83 1461-1470. (doi:10.1046/j.1471-4159.2002.01231.x)

Lachowicz JE, Shen Y, Monsma FJ Jr \& Sibley DR 1995 Molecular cloning of a novel $\mathrm{G}$ protein-coupled receptor related to the opiate receptor family. Journal of Neurochemistry 64 34-40. (doi:10.1046/j. 1471-4159.1995.64010034.x)

Lapalu S, Moisand C, Mazarguil H, Cambois G, Mollereau C \& Meunier JC 1997 Comparison of the structure-activity relationships of nociceptin and dynorphin A using chimeric peptides. FEBS Letters 417 333-336. (doi:10.1016/S0014-5793(97)01318-5)

Lieschke GJ \& Currie PD 2007 Animal models of human disease: zebrafish swim into view. Nature Reviews. Genetics 8 353-367. (doi:10.1038/nrg2091)

McClendon J, Lecaude S, Dores AR \& Dores RM 2010 Evolution of the opioid/ORL-1 receptor gene family. Annals of the New York Academy of Sciences 1200 85-94. (doi:10.1111/j.1749-6632.2010.05515.x)

Meng F, Taylor LP, Hoversten MT, Ueda Y, Ardati A, Reinscheid RK, Monsma FJ, Watson SJ, Civelli O \& Akil H 1996 Moving from the orphanin FQ receptor to an opioid receptor using four point mutations. Journal of Biological Chemistry 271 32016-32020. (doi:10.1074/jbc.271.50.32016)

Meng F, Ueda Y, Hoversten MT, Taylor LP, Reinscheid RK, Monsma FJ, Watson SJ, Civelli O \& Akil H 1998 Creating a functional opioid alkaloid binding site in the orphanin $\mathrm{FQ}$ receptor through sitedirected mutagenesis. Molecular Pharmacology 53 772-777.

Metzger TG \& Ferguson DM 1995 On the role of extracellular loops of opioid receptors in conferring ligand selectivity. FEBS Letters 375 1-4. (doi:10.1016/0014-5793(95)01185-H)

Meunier JC 1997 Nociceptin/orphanin FQ and the opioid receptorlike ORL1 receptor. European Journal of Pharmacology 340 1-15. (doi:10.1016/S0014-2999(97)01411-8)

Meunier JC, Mollereau C, Toll L, Suaudeau C, Moisand C, Alvinerie P, Butour JL, Guillemot JC, Ferrara P, Monsarrat B et al. 1995 Isolation and structure of the endogenous agonist of opioid receptor-like ORL1 receptor. Nature 377 532-535. (doi:10.1038/ 377532a0)

Mogil JS \& Pasternak GW 2001 The molecular and behavioral pharmacology of the orphanin $\mathrm{FQ} /$ nociceptin peptide and receptor family. Pharmacological Reviews 53 381-415.

Mollereau C \& Mouledous L 2000 Tissue distribution of the opioid receptor-like (ORL1) receptor. Peptides 21 907-917. (doi:10.1016/ S0196-9781(00) 00227-8)

Mollereau C, Parmentier M, Mailleux P, Butour JL, Moisand C, Chalon P, Caput D, Vassart G \& Meunier JC 1994 ORL1, a novel member of the opioid receptor family. Cloning, functional expression and localization. FEBS Letters 341 33-38. (doi:10.1016/0014-5793(94) 80235-1)

Mollereau C, Moisand C, Butour JL, Parmentier M \& Meunier JC 1996 Replacement of Gln280 by His in TM6 of the human ORL1 receptor increases affinity but reduces intrinsic activity of opioids. FEBS Letters 395 17-21. (doi:10.1016/0014-5793(96) 00993-3)

Mollereau C, Mouledous L, Lapalu S, Cambois G, Moisand C, Butour JL \& Meunier JC 1999 Distinct mechanisms for activation of the opioid receptor-like 1 and kappa-opioid receptors by nociceptin and dynorphin A. Molecular Pharmacology 55 324-331.

Mouledous L, Topham CM, Moisand C, Mollereau C \& Meunier JC 2000 Functional inactivation of the nociceptin receptor by alanine substitution of glutamine 286 at the $\mathrm{C}$ terminus of transmembrane segment VI: evidence from a site-directed mutagenesis study of the ORL1 receptor transmembrane-binding domain. Molecular Pharmacology 57 495-502. 
New DC \& Wong YH 2002 The ORL1 receptor: molecular pharmacology and signalling mechanisms. Neurosignals 11 197-212. (doi:10.1159/000065432)

Nishi M, Takeshima H, Fukuda K, Kato S \& Mori K 1993 cDNA cloning and pharmacological characterization of an opioid receptor with high affinities for kappa-subtype-selective ligands. FEBS Letters 330 77-80. (doi:10.1016/0014-5793(93)80923-I)

Osinski MA, Pampusch MS, Murtaugh MP \& Brown DR 1999 Cloning, expression and functional role of a nociceptin/orphanin FQ receptor in the porcine gastrointestinal tract. European Journal of Pharmacology 365 281-289. (doi:10.1016/S0014-2999(98)00869-3)

Pan YX, Xu J \& Pasternak GW 1996 Structure and characterization of the gene encoding a mouse kappa3-related opioid receptor. Gene 171 255-260. (doi:10.1016/0378-1119(95)00890-X)

Pinal-Seoane N, Martin IR, Gonzalez-Nunez V, de Velasco EM, Alvarez FA, Sarmiento RG \& Rodriguez RE 2006 Characterization of a new duplicate delta-opioid receptor from zebrafish. Journal of Molecular Endocrinology 37 391-403. (doi:10.1677/jme.1.02136)

Reinscheid RK, Nothacker HP, Bourson A, Ardati A, Henningsen RA, Bunzow JR, Grandy DK, Langen H, Monsma FJ Jr \& Civelli O 1995 Orphanin FQ: a neuropeptide that activates an opioidlike $\mathrm{G}$ protein-coupled receptor. Science 270 792-794. (doi:10.1126/ science.270.5237.792)

Reinscheid RK, Ardati A, Monsma FJ Jr \& Civelli O 1996 Structureactivity relationship studies on the novel neuropeptide orphanin FQ. Journal of Biological Chemistry 271 14163-14168. (doi:10.1074/ jbc.271.24.14163)

Rizzi A, Calo G, Trevisani M, Tognetto M, Fabbri L, Mapp C, Guerrini R, Salvadori S, Regoli D \& Geppetti P 1999 Nociceptin receptor activation inhibits tachykinergic non adrenergic non cholinergic contraction of guinea pig isolated bronchus. Life Sciences $\mathbf{6 4}$ L157-L163. (doi:10.1016/S0024-3205(99)00045-4)

Sanchez-Simon FM \& Rodriguez RE 2008 Developmental expression and distribution of opioid receptors in zebrafish. Neuroscience $\mathbf{1 5 1}$ 129-137. (doi:10.1016/j.neuroscience.2007.09.086)

Stevens CW, Brasel CM \& Mohan S 2007 Cloning and bioinformatics of amphibian mu, delta, kappa, and nociceptin opioid receptors expressed in brain tissue: evidence for opioid receptor divergence in mammals. Neuroscience Letters 419 189-194. (doi:10.1016/j.neulet. 2007.04.014)
Tamura K, Dudley J, Nei M \& Kumar S 2007 MEGA4: Molecular Evolutionary Genetics Analysis (MEGA) software version 4.0. Molecular Biology and Evolution 24 1596-1599. (doi:10.1093/molbev/ msm092)

Thompson JD, Higgins DG \& Gibson TJ 1994 CLUSTALW: improving the sensitivity of progressive multiple sequence alignment through sequence weighting, position-specific gap penalties and weight matrix choice. Nucleic Acids Research 22 4673-4680. (doi:10.1093/ nar/22.22.4673)

Vincent B, Mouledous L, Bes B, Mazarguil H, Meunier JC, Milon A \& Demange P 2008 Description of the low-affinity interaction between nociceptin and the second extracellular loop of its receptor by fluorescence and NMR spectroscopies. Journal of Peptide Science 14 1183-1194. (doi:10.1002/psc.1057)

Waldhoer M, Bartlett SE \& Whistler JL 2004 Opioid receptors. Annual Reviews of Biochemistry 73 953-990. (doi:10.1146/annurev.biochem. 73.011303.073940)

Walthers EA, Bradford CS \& Moore FL 2005 Cloning, pharmacological characterization and tissue distribution of an ORL1 opioid receptor from an amphibian, the rough-skinned newt Taricha granulosa. Journal of Molecular Endocrinology 34 247-256. (doi:10.1677/jme.1. 01687)

Wang JB, Johnson PS, Imai Y, Persico AM, Ozenberger BA, Eppler CM \& Uhl GR 1994 cDNA cloning of an orphan opiate receptor gene family member and its splice variant. FEBS Letters 348 75-79. (doi:10.1016/0014-5793(94)00557-5)

Wick MJ, Minnerath SR, Lin X, Elde R, Law PY \& Loh HH 1994 Isolation of a novel cDNA encoding a putative membrane receptor with high homology to the cloned mu, delta, and kappa opioid receptors. Brain Research. Molecular Brain Research 27 37-44. (doi:10. 1016/0169-328X(94)90181-3)

Zon LI \& Peterson RT 2005 In vivo drug discovery in the zebrafish. Nature Reviews. Drug Discovery 4 35-44. (doi:10.1038/nrd1606)

Received in final form 16 December 2010

Accepted 18 January 2011

Made available online as an Accepted Preprint 19 January 2011 